\title{
Dinamika Sosial Kehidupan Pengusaha Warung Makan
}

\author{
Muhammad Yusran \\ Hidayah Quraisy \\ Universitas Muhammadiyah Makassar \\ hidayahquraisy@unismuh.ac.id \\ St. Fatimah Tola \\ Universitas Muhammadiyah Makassar \\ sitifatimahtola@unismuh.ac.id
}

\begin{abstract}
ABSTRAK
Penelitian ini bertujuan untuk mengetahui yang melatar belakangi masyarakat di Kelurahan Mosso memilih usaha warung makan dan bagaimanakah dinamika sosial kehidupan pengusaha warung makan dalam menjalankan aktivitas sehari-harinya.Metode peneltian ini menggunakan penelitian kualitatif dimana penelitian kualitatif merupakan penelitian yang tidak menggunakan sumber datanya berupa angka-angka melainkan menggunakan penggambar yang terjadi dilapangan melalui wawancara, dokumentasi, dokumentasi, dan lain-lain.Sumber data yang digunakan adalah data primer dan data skunder. Teknik analisis data melalui bebrapa tahap mulai dari pengumpulan data, reduksi data, display data dan penarikan kesimpulan, sedangkan teknik keabsahan data yang digunakan melalui trianggulasi sumber, waktu dan teknik. Hasil penelitian menunjukan latar belakang masyarakat di Kelurahan Mosso memilih menjadi pengusaha warung makan karena faktor ekonomi, dorongan dari keluarga, lokasi yang strategis dan rendahnya tingkat pendidikan, 2. Dinamika kehidupan sosial pengusaha warung makan adalah hubungan sosial di tempat kerja, hubungan sosial di keluarga, dan hubungan sosial di masyarakat.
\end{abstract}

Kata Kunci : Dinamika Sosial, Pengusaha, Warung Makan.

\section{PENDAHULUAN}

Perubahan selalu berlaku pada semua masyarakat, setiap saat di manapun manusia hidup dan beradad, walaupun dalam taraf yang paling kecil sekalipun, masyarakat yang di dalamnya terdiri atas banyak sekali individu akan selalu berubah. Perubahan tersebut dapat berupa perubahan yang kecil sampai taraf perubahan yang sangat besar bagi aktivitas atau perilaku manusia. Perubahan dapat mencakup aspek yang sempit maupun yang luas. Aspek yang sempit dapat meliputi aspek perilaku dan pola pikir individu. Aspek yang luas dapat berupa perubahan dalam tingkat struktur masyarakat yang nantinya dapat memengaruhi perkembangan masyarakat di masa yang akan datang. Perubahan-perubahan dapat ditemukan apabila membandingkan susunan dan kehidupan masyarakat pada suatu waktu dengan pada waktu yang lampau.Perubahan-perubahan yang terjadi pada masyarakat dewasa ini merupakan gejala yang normal. Pengaruhnya bisa menjalar dengan cepat berkat adanya komunikasi modern. Penemuan-penemuan baru 
di bidang teknologi yang terjadi di suatu tempat, dengan cepat dapat diketahui oleh masyarakat lain yang berada jauh dari tempat tersebut. Kemiskinan di Indonesia masih menjadi masalah dalam pembangunan, hal ini disebabkan rendahnya taraf pendidikan, rendahnya derajat kesehatan, terbatasnya lapangan kerja, dan kondisi terisolasian. Kemiskinan sebagai realitas kehidupan selalu digambarkan sebagai suatu keadaan kehidupan yang kekuarangan, lemah dan tidak berkecukupan dalam memenuhi kebutuhan hidupnya, baik dalam pengertian spiritual maupun material.Masih tingginya angka kemiskinan dan pengangguran karena sempitnya lapangan pekerjaan membuat masyarakat berinisiatif untuk membuka usaha-usaha pemenuhan ekonomi melalui sektor informal. Sektor informal adalah sektor yang tidak terorganisasi, tidak teratur, dan kebanyakan legal tapi tidak terdaftar. Sektor informal sangat berkembang dalam masyarakat karena mudah dijangkau seluruh kalangan masyarakat, salah satunya adalah usaha makanan.

Usaha makanan adalah usaha membuat dan menjual makanan . usaha makanan merupakan usaha yang banyak diminati masyarakat karena modal usaha yang tidak terlalu besar dan tidak mengharuskan berpendidikan tinggi. Hal ini banyak nampak seperti yang terjadi di Kelurahan Mosso, Kecamatan Sendana Kabupaten Majene. Usaha makanan juga terlihat berjajar di Lingkungan Labuang Soba. Banyak dari warga Lingkungan Labuang Soba yang membuka usaha makanan yaitu 77 usaha makanan. Lingkungan Labuang Soba menjadi kawasan yang berada di pinggir jalan poros Sul-Bar, sehingga banyak angkutan umum yang lewat disekitar lokasi warung makan. Kebanyakan orang-orang yang melakukan perjalanan tersebut singgah istirahat dan sekaligus menikmati makanan yang ada di warung tersebut.Kebutuhan-kebutuhan para pendatang yang sedang dalam perjalanan menjadi keuntungan tersendiri bagi masyarakat Lingkungan Labuang Soba, karena dengan semakin banyaknya pendatang maka hal ini membuka ruang usaha baru untuk pemenuhan kebutuhan-kebutuhan mereka. Pada awalnya warung makan yang membuka usaha di sepanjang jalan majene tersebut jumlahnya relatif sedikit, namun semakin lama semakin bertambah banyak dan berlokasi pada tempat-tempat strategis dihampir sepanjang jalan Majene. Puluhan kendaraan roda empat maupun roda dua terlihat menumpuk di tempat wisata kuliner pengasapan Ikan Terbang yang terletak di jalur trans Sulawesi sekitar 25 kilometer dari kota Majene. Ikan terbang atau ikan Tuing-Tuing sebutan orang Mandar maupun orang Bugis, Makassar ini semenjak beberapa tahun terakhir menjadi incaran bagi pengguna jalan khususnya pada 
saat perjalanan arus balik setelah lebaran. Lokasi tempat wisata kuliner pengasapan ikan terbang di Somba sangat mudah dijumpai oleh masyarakat yang hendak mencicipi makanan khas masyarakat Mandar ini yakni melihat deretan warung makan disertai kepulan asap di wilayah jalan trans Sulawesi. Masyarakat yang mencicipi makanan khas ikan asap terbang dengan menu makanan trandisional "Jepa" atau hasil olahan bahan baku ubi kayu ini harganya pun relatif terjangkau. Warga yang menikmati makanan khas tradisional ikan terbang ini lantaran ada yang penasaran dan ada pula yang sekedar jalanjalan.

\section{LANDASAN TEORI}

Proses-proses sosial itu tumbuh dan dapat kita hayati bila terjadi pertemuanpertemuan antara dua orang atau kelompok, serta membentuk sistem-sistem hubungan atau terjadi perubahan-perubahan bila cara hidup yang telah ada diganggu. Masyarakat dalam aspek-aspek dinamikanya terdiri atas individu-individu dari kelompok dalam interaksinya. Proses ini merupakan fase dari interaksi itu. Seperti telah kita maklumi seseorang itu tidak bisa lari daripada hidup berkelompok. Kelompok ini coraknya beraneka ragam, dari yang paling sederhana, misalnya adalah, dalam suatu keluarga atau dalam bentuk kelompok tetangga sampai pada gabungan masyarakat yang kompleks, Negara, nasional. Seseorang dapat menjadi anggota dan pelbagai macam kelompokkelompok keluarga , tetangga, keagamaan, kelompok olah raga, keguruan, kewanitaan, dan organisasi-organisasi lain. Morenomengemukakan bahwa perlunya "kelompokkelompok kecil seperti keluarga, klik, regu kerja, regu belajar, dimana dalam kelompokkelompok itu terdapat suasana saling menolong, sehingga kohesi makin kuat dan kelompok yang makin kuat kohesinya, makin besar moralnya". Dalam hal ini Morenotelah menunjukkan dengan jelas adanya kelompok-kelompok yang lebih konkret dari pada ahli-ahli psikologi sosial dan Moreno menunjukkan pula pengaruh kelompok tersebut terhadap kehidupan individu dalam kelompok itu.

Hubungan kerja merupakan hasil dari adanya interaksi yang dapat menimbulkan kerjasama, karena orientasi orang perorangan terhadap kelompoknya dan bahkan terhadap kelompok lainnya, seperti yang dikemukakan oleh Soerjono Soekanto (1987:192) bahwa di dalam kelompok-kelompok manusia memerlukan perlindungan dari rekan-rekannya, manusia mempunyai kemampuan yang terbatas didalam pergaulan hidup dan lain sebagainya.Menuruut Lyon (2000) modal sosial berasal dari interaksi dari 
berbagai faktor yang masing-masing memerlukan hubungan sosial yang membentuk bagaimana masyarakat bereaksi, dan reaksi-reaksi ini dibentuk oleh modal sosial yang ada. Secara umum modal sosial bisa didekati dari dua perspektif. Pertama, mengkaji modal sosial dari perspektif pelaku (actor's perspective) yang diformulasikan oleh Bourdieu, yang melihat modal sosial berisi sumber daya, di mana pelaku individu dapat menggunakannya kerena kepemilikannya terhadap jaringan secara eksklusif (exclusive networks). Kedua, mencermati modal sosial dari perspektif masyarakat (society's perspective) yang dikonseptualisasikan oleh Putnam, yang melihat modal sosial sebagai barang publik yang diatur oleh organisasi dan jaringan horizontal yang eksis dalam masyarakat. Coleman melihat langsung dari dua sudut pandang tersebut, tetapi dengan cakupan yang lebih luas (wider range) mengenai bentuk-bentuk modal sosial, termasuk ekspektasi, norma, dan sanksi (Rosyadi, 2003).Burt (dalam Portes, 1998) memaknai modal sosial sebagai teman, kolega, dan lebih umum kontak lewat siapa pun yang membuka peluang bagi pemanfaatan modal ekonomi dan manusia. Uphoff (dalam Yustika, 2013) juga menyatakan bahwa modal sosial dapat ditentukan sebagai akumulasi dari beragam tipe dari aspek sosial, psikologi, budaya, kelembagaan, dan aset yang tidak terlihat (intangible) yang mempengaruhi perilaku kerjasama.Secara harfiah, struktur bisa diartikan sebagai susunan atau bentuk. Struktur tidak harus dalam bentuk fisik, ada pula struktur yang berkaitan dengan sosial. Menurut ilmu sosiologi, struktur sosial adalah tatanan atau susunan sosial yang membentuk kelompok-kelompok sosial dalam masyarakat. Susunannya bisa vertikal atau horizontal.

Ritzer dan Goodman dalam Teori Sosiologi Modern Edisi Keenam (2008), banyak mengemukakan pendapat para ahli sosiologi yang merumuskan definisi struktur sosial, antara lain sebagai berikut :George Simmel mendenifisikan struktur sosial sebagai kumpulan individu serta pola perilakunya, sedangkan George C. Homans mendefinisikan struktur sosial merupakan hal yang memiliki hubungan erat dengan perilaku sosial dasar dalam kehidupan sehari-hari, dan William Kornblum mendenifisikan struktur sosial adalah susunan yang dapat terjadi karena adanya pengulangan pola perilaku individu.Sehingga teori struktur sosial merupakan, salah satu teori yang lahir atas fenomena yang terjadi dimasyarakat. Fenemona sosial yang terjadi dalam kehidupan manusia, merupakan suatu interaksi antara manusia dengan lingkungan alam. Bahkan hubungan antara manusia dengan sang penciptanya. Hal ini mengingat bahwa manusia merupakan sebagai makhluk sosial yang tidak bisa lepas dari antar keterkaitan manusia 
yang satu dengan satunya.Menurut Talcott Parsons, kehidupan sosial itu harus dipandang sebagai sebuah sistem (sosial). Ia mengatakan bahwa dalam Narwoko dan Suyanto (2006: 125) sebuah sistem sosial dapat didefenisikan sebagai suatu pola interaksi sosial yang terjadi dari komponen sosial yang teratur dan melembaga. Salah satu karakteristik sistem sosial adalah merupakan kumpulan dari beberapa unsur atau komponen yang terdapat dalam masyarakat, dimana komponen-kompenen tersebut saling berhubungan dan saling tergantung satu sama lain.

Kehidupan sosial sebagai suatu sistem sosial memerlukan terjadinya ketergantungan yang berimbas pada kestabilan sosial. Sistem yang timpang karena tidak adanya kesadaran bahwa mereka merupakan sebuah kesatuan, menjadikan sistem tersebut tidak teratur. Suatu sistem sosial akan selalu terjadi keseimbangan apabila ia menjaga Safety Valve (katup pengaman). Hal tersebut telah dikemukakan oleh Talcott Parsons. Menurutnya, sistem sosial dapat di analisa melalui persyaratan-persyaratan fungsional yang harus dimiliki sebuah sistem sosial. Sistem sosial itu dapat dikembangkan jika memenuhi persyaratan-persyaratan fungsional dalam kerangka A-G-I-L.Dalam konteks kehidupan bermasyarakat suatu konsep bagi mereka yang dianggap bernilai tinggi bahwa manusia itu pada hakekatnya tidak berdiri sendiri akan tetapi dikelilingi oleh masyarakat. Sehingga ia merasa dirinya sebagai unsur kecil saja dalam lingkungan sosialnya.Hubungan sosial merupakan syarat utama terjadinya kegiatan yang berlangsung dalam suatu masyarakat seperti yang dikemukakan oleh Syani (1987:43). Yang mengemukakan bahwa interaksi sosial merupakan syarat utama terjadinya aktifitas sosial. Interaksi sosial merupakan hubungan sosial yang dinamis yang menyangkut hubungan orang perorangan, antara kelompok dengan kelompok, maupun antara perorangan dengan kelompok."

Berbagai kepustakaan memberi penjelasan tentang hubungan sosial dan interaksi sosial baik langsung maupun tidak langsung memberikan arti yang sama dalam kedua hal tersebut. Hal ini lebih jelas kita lihat uraian Syani (1987:52). Yang mengemukakan bahwa interaksi sosial identik dengan hubungan sosial karena, adanya hubungan sosial berarti sekaligus sudah merupakan interaksi sosial. Dikatakan demikian karena didalam interaksi sosial terdapat hubungan antara satu dengan yang lainnya yang saling memberi dan menerima dengan mewujudkan suatu kerja sama atau mungkin terjadi suatu persaingan maupun pertentangan. Aspek sosial ekonomi merupakan aspek yang tidak bisa terlepas dari kehidupan manusia, dalam hal ini aspek ekonomi seseorang yang terdiri atas 
pendapatan, kebutuhan pokok, dan pemeliharaan harta benda merupakan cermin dari tingkat hidup seseorang dapat diukur dengan keadaan ekonomi yang bersangkutan sehubungan dengan hal ini Mubyarto (1985:23) mengatakan bahwa Tingkat kesejahteraan dapat diukur dengan aspek ekonomi yaitu jumlah pendapatan, macam dan jumlah barang yang dimiliki atau yang dikuasai secara kebebasan untuk menentukan barang atau usaha apa yang dilakukan untuk meningkatkan kepuasan hidupnya”.

Perubahan sosial dapat dibayangkan sebagai perubahan yang terjadi di dalam atau mencangkup sistem sosial. Lebih tepatnya, terdapat perbedaan antara keadaan sistem tertentu dalam jangka waktu berlainan. Berbicara tentang perubahan, menurut Strasser \& Randel yang dikutip Szotompka (2007; 3), yaitu dengan membayangkan sesuatu yang terjadi setelah jangka waktu tertentu; berurusan dengan perbedaan keadaan yang diamati antara sebelum dan sesudah jangka waktu tertentu. Untuk mendapatkan perbedaannya, ciri-ciri awal unit analisis harus diketahui dengan cermat meski terus berubah. Jadi konsep dasar perubahan sosial mencangkup tiga gagasan yaitu perbedaan, waktu berbeda dan di antara keadaan sistem sosial yang sama.Gillin dan Gillin juga mengungkapkan teori perubahan sosial dengan menyatakan bahwa Perubahan sosial adalah suatu variabel dari cara-cara hidup yang telah diterima oleh masyarakat, yang disebabkan oleh adanya perubahan kondisi geografis,kebudayaan material, komposisi penduduk, ideologi maupun karena adanya difusi dan penemuan baru dalam masyarakat (Soekanto, 2010: 304)"

\section{METODE PENELITIAN}

Dasar penelitian yang digunakan dalam penelitian ini adalah studi kasus, yaitu suatu pendekatan untuk melihat objek penelitian sebagai suatu kesatuan yang terpadu agar dapat memperoleh fakta yang meyakinkan. Metode peneltian ini menggunakan penelitian kualitatif dimana penelitian kualitatif merupakan penelitian yang tidak menggunakan sumber datanya berupa angka-angka melainkan menggunakan penggambar yang terjadi dilapangan melalui wawancara, dokumentasi, dokumentasi, dan lain-lain. Sumber data yang digunakan adalah data primer dan data skunder. Teknik analisis data melalui bebrapa tahap mulai dari pengumpulan data, reduksi data, display data dan penarikan kesimpulan, sedangkan teknik keabsahan data yang digunakan melalui trianggulasi sumber, waktu dan teknik.

\section{PEMBAHASAN}


Dalam bagian ini akan dibahas hasil penelitian yang diperoleh setelah melakukan observasi, wawancara serta dokumentasi tentang Dinamika Sosial Kehidupan Pengusaha Warung Makan di Kelurahan Mosso. Untuk lebih jelasnya dipaparkan sebagai berikut :Masih tingginya angka kemiskinan dan pengangguran karena sempitnya lapangan pekerjaan membuat masyarakat berinisiatif untuk membuka usaha-usaha pemenuhan ekonomi melalui sektor informal, konsep ini sering dipakai untuk menjelaskan bahwa sektor informal dapat mengurangi pengangguran di kota Negara sedang bekembang. Sektor informal merupakan strategi untuk menyelesaikan masalah terbatasnya peluang kerja. Sektor informal berfungsi untuk meredam ledakan sosial sebagai akibat meningkatnya pencari kerja, baik dalam kota maupun pendatang dari desa.Unit usaha yang berada disektor informal semuanya termasuk ke dalam ekonomi lemah. Lemahnya ketahanan ekonomi yang dimiliki oleh unit usaha di sektor informal karena pada umumnya golongan tersebut tidak atau belum memperoleh proteksi ekonomi dari pemerintah. Maka dari itu, sebagian masyarakat yang berada di Kelurahan Mosso memilih menjadi pengusaha warung makan. . Dari hasil penelitian yang dilakukan di dapati bahwa ada beberapa faktor yang melatar belakangi masyarakat di Kelurahan Mosso memilih menjadi pengusaha warung makan, yaitu: 1) Faktor ekonomi, melihat tuntutan biaya hidup yang semakin hari semakin tinggi dan tidak dapat dipungkiri bahwa faktor ekonomilah yang menunjang terpenuhinya kebutuhan pokok manusia untuk melangsungkan kehidupannya; (2) Pendidikan yang Terlampau Rendah. Tingkat pendidikan yang rendah menyebabkan seseorang kurang mempunyai keterampilan tertentu yang diperlukan dalam kehidupannya. Keterbatasan pendidikan atau keterampilan yang dimiliki seseorang menyebabkan keterbatasan kemampuan seseorang untuk masuk dalam dunia kerja; (3) keluarga. Adanya dukungan kuat dari keluarga untuk menjalankan usaha warung makan; (4) Lingkungan. Lingkungan yang strategis mendorong seseorang untuk mendirikan warung makan di lingkungan sekitar tempat tinggalnya, karena melihat keuntungan yang didapatkan. Keterbatasan lapangan kerja akan membawa konsekuensi pengangguran bagi masyarakat. Mendirikan usaha warung makan merupakan kreatifitas berfikir oleh seseorang agar terpenuhi kebutuhan hidupnya. Meskipun pendapatan yang dihasilkan tidak seberapa, namun mampu memenuhi kebutuhan hidup mereka sehari-hari.

Usaha warung makan tidak dikerjakan oleh satu orang saja, melainkan ada beberapa warung makan yang mempekerjakan karyawan dan ada pula seluruh anggota 
keluarga ikut bekerja dalam satu warung makan. Hal tersebut menandakan adanya hubungan kerja yang terlihat secara abstrak karena adanya kerja sama yang baik antar anggota dalam menjalankan usaha warung makan. Sebagaimana yang dikemukakan oleh Soerjono Soekanto (1987:237) bahwa kerjasama timbul apabila orang menyadari bahwa mereka mempunyai kepentingan-kepentingan yang sama pada saat yang bersamaan mempunyai cukup pengetahuan dan pengendalian terhadap diri sendiri untuk memenuhi kepentingan-kepentingan tersebut melalui kerja sama kesadaran akan adanya organisasi merupakan fakta-fakta yang penting dalam kerjasama yang berguna. Selain hal diatas modal sosial juga penting untuk dimiliki oleh para pengusaha warung makan. Sebagaimana yang dikemukakan oleh Lesser (2000), modal sosial sangat penting bagi komunitas karena (1) memberikan kemudahan dalam mengakses informasi bagi anggota komunitas; (2) menjadi media pembagian kekuasaan dalam komunitas; (3) mengembangkan solidaritas; (4) memungkinkan mobilisasi sumber daya komunitas; (5) memungkinkan pencapaian bersama; dan (6) membentuk perilaku kebersamaam dan berorganisasi komunitas.Dimana aspek sosial ekonomi merupakan aspek yang tidak pernah terlepas dari kehidupan manusia. Apabila aspek ekonomi terpenuhi dengan baik, maka akan berpengaruh pula pada tingkat kesejahteraan seseorang. Bagitu halnya juga dengan kehidupan sosial seseorang akan mampu terpenuhi apabila aspek sosial ekonomi mereka terpenuhi. Kehidupan sosial yang dimaksud adalah pendidikan yang tinggi dan keterampilan. sehubungan dengan hal ini Mubyarto (1985:23) mengatakan bahwa tingkat kesejahteraan dapat diukur dengan aspek ekonomi yaitu jumlah pendapatan, macam dan jumlah barang yang dimiliki atau yang dikuasai secara kebebasan untuk menentukan barang atau usaha apa yang dilakukan untuk meningkatkan kepuasan hidupnya.

Sesuai dengan beberapa pendapat yang telah dikemukakan diatas maka seseorang yang memiliki ekonomi yang lemah harus mampu membuka lapangan pekerjaan sendiri. Sebuah usaha warung makan menjadi alternatif yang mujarab digeluti oleh sebagian masyarakat di Kelurahan Mosso. Usaha warung makan tersebut sangat membantu masyarakat disana untuk memenuhi kebutuhan sehari-hari mereka. Usaha warung makan merupakan sebuah usaha sektor informal, dimana usaha tersebut tidak terikat oleh pemerintah, tidak terikat oleh jam kerja sebagaimana jam kerja yang diterapkan di kantorkantor, serta usaha warung makan juga tidak membutuhkan modal yang banyak, tidak harus berpendidikan yang tinggi, namun tetap saja menghasilkan pendapatan yang paspasan. Dengan demikian, adanya usaha warung makan di Kelurahan Mosso banyak 
membantu perekonomian masyarakat di kelurahan tersebut. Usaha warung makan menimbulkan adanya hubungan simbiosis mutualisme atau hubungan yang saling menguntungkan antara pemilik warung makan dengan masyarakat setempat karena mereka yang menyediakan makanan seperti ikan, buras, jepa,dan sokkol lameayu untuk dijual kepada pemilik usaha warung makan.

\section{KESIMPULAN}

Setelah melalui proses pembahasan terhadap permasalahan yang telah dirumuskan, maka sampailah kita pada penarikan kesimpulan yang berdasar pada hasil analisis data. Adapun beberapa kesimpulan tersebut sebagai betikut.

1. Hal-hal yang melatar belakangi masyarakat di Kelurahan Mosso Majene memilih usaha warung makan yaitu :

Faktor utama informan membuka usaha warung makan adalah karena faktor ekonomi.Melihat tuntutan biaya hidup yang semakin hari semakin tinggi apalagi pada zaman sekarang ini, kebutuhan-kebutuhan pokok di pasaran semakin mahal.Listrik, air, BBM pun semakin melonjak tinggi.Kesemuanya itu menuntut informan untuk bekerja dan menghasilkan uang yang lebih banyak lagi supaya hidup tidak kekurangan apapun.Selain itu juga, rendahnya tingkat pendidikan yang mereka miliki, menyulitkan mereka untuk mendapatkan pekerjaan yang lebih baik, karena dibutuhkan spesialisasi khusus untuk bisa mendapatkan pekerjaan tersebut.

2. Dinamika sosial pawwarung

a. Hubungan sosial di tempat kerja dan tempat tinggal

Informan umumnya penduduk asli tempat mereka bekerja yaitu di Kelurahan Mosso.Hal tersebutlah yang membuat tingkat solidaritas di antara informan cukup tinggi, seperti dalam hal menjenguk jika ada teman yang sakit, saling meminjamkan uang jika ada yang kekurangan uang.

b. Hubungan sosial dengan keluarga

Sikap dan perlakuan anggota keluarga terhadapa informan yang bekerja di warung makan sangat mendukung informan.Karena keluarga berharap banyak pada pekerjaan informan dalam hal pembiayaan hidup sehari-hari.

c. Hubungan sosial dengan masyarakat

Hubungan informan dengan masyarakat di sekitar mereka cukup baik. Apabila informan bersikap baik terhadap para warga maka warga juga akan baik terhadap 
mereka, namun jika informan bersikap buruk maka warga tidak segan-segan mencela dan terkadang menjatuhkan nama baik informan kepada calon pelanggan yang kebetulan bertanya kepada warga tentang warung makan yang baik atau tidak untuk ditempati makan.

\section{DAFTAR PUSTAKA}

Ahmadin. (2013) .Metode Penelitian Sosial.Makassar: Raihan Intermedia.

Anonim.(2012). Pengertian Pendidikan Menurut Para Ahli, Artikel Pendidikan (Online), (http://carakata. blogspot. com, diakses 30 Maret 2015, pukul 23.50).

Datau, Edi. (1992). Kehidupan Sosial Ekonomi Petani Penggarap Sawah.Makassar. Skripisi Unhas.

Field John.(2010). Modal Sosial.Yogyakarta: Kreasi Wacana.

Ishak, Nailah. (2002). Dinamika Kehidupan Sosial Pawwarung di Desa Siawung Kecamatan Barru Kabupaten Barru.Makassar. Skripisi Unhas.

Jack, Andis. (2013). Analisis Perbedaan Teori Struktur, Artikel Teori Sosiologi, (Online),(http://andikajack. com, diakses 7 April 2015, pukul 18.45).

Lauer, Robert. H. (1993).Perspektif tentang Perubahan Sosial. Jakarta: PT. Rhineka Cipta.

Lawang, Robert M.Z. (1986). Terori Sosiologi Klasik dan Modern. Jakarta: PT. Gramedia.

Mubyarto, (1997).Pengantar Ekonomi Pertanian. LP3ES, Yogyakarta.

Narwoko, J. Dewi \& Suyanto Bagon.(2011). Sosiologi Teks Pengantar dan Terapan. Jakarta: Kencana.

Poloma, Margaret M. (2010). Sosiologi Kontemporer. Jakarta : PT. Raja Grafindo Persada.

Pras.(2013). Teori Kebutuhan Abraham Maslow, Artikel teori Sosiologi, (Online), (http://www.praswck.com, diakses 7 April 2015, pukul 12.00).

Ritzer, George. (2007). Sosiologi Ilmu Pengetahuan Berparadigma Ganda.Jakarta : PT. Raja Grafindo Persada.

Syani, Abdul. (1987). Sosiologi Kelompok dan Masalah Sosial.Fajar Agung. Jakarta.

Soekanto, Soerjono. (1990). Sosiologi Suatu Pengantar.Rajawali Pers, Jakarta.

Santoso, Slamet. (1999). Dinamika Kelompok. Bumi Aksara, Jakarta. 
Soekanto, Soerjono. (2005). Sosiologi Suatu Pengantar.Jakarta : Raja Grafiindo Persada.

Soekanto, Soerjono. (2010). Sosiologi Suatu Pengantar.Jakarta : Rajawali Press.

Sugiono.( 2011). Meotode Penelitian Kuantitatif, Kualitatif dan R\&D. Bandung: Alfabeta.

Sztompka, Piotr. (2010). Sosiologi Perubahan Sosial.Edisi Pertama Cetakan Kelima. Prenada Media Group : Jakarta. 